\title{
Research on the Influencing Factors of China's OFDI Based on Principal Component Analysis
}

\author{
Yamei Zhang \\ Yunnan university of finance and economics \\ International business school \\ Kunming, China \\ 624209199@qq.com
}

\author{
Ying Yang* \\ Yunnan university of finance and economics \\ International business school \\ Kunming, China \\ 11476423@qq.com
}

\begin{abstract}
The continuous advancement of China's "going out" policy has made China's deeper economic and trade cooperation with overseas host countries and countries along the line closer, and actively promoted the development of foreign investment. This study selects the relevant data of China's Outward foreign direct investment from 2000 to 2015, and uses the principal component analysis model to explore the factors affecting the development of China's OFDI. From the relevant conclusions, certain policy recommendations are made for OFDI of the relevant countries.
\end{abstract}

Keywords: foreign direct investment, principal component analysis, influencing factors

\section{INTRODUCTION}

Entering the 21st century, China's opening up to the outside world has entered a new stage, from the original "introduction" to the "introduction" and "going out" equal emphasis. In 2000, China established and implemented the "going out" strategy; in 2002, the "10th Five-Year Plan" was formulated to make full use of both domestic and foreign resources and two markets; in 2013, China's "The Belt and Road" strategy began to be implemented. The Chinese government's continuous improvement of the "going out" policy and "The Belt and Road" strategy not only strengthened deep economic and trade cooperation with other countries, but also actively promoted foreign investment; it also took into account the quality and efficiency of opening up to the domestic supply-side structure. Sexual reforms and economic growth shift adjustments have created good external conditions. Thanks to China's growing economic strength, international influence and policy support, China has now become one of the world's largest exporters of capital and technology.

Outward Foreign Direct Investment (OFDI), which connects the home and host markets of investment enterprises, is the economic behavior of a country's investors exporting intangible assets such as capital, technology and management skills in order to gain effective control over the operation and management of foreign enterprises, and in order to optimize the transnational allocation of factors of production, improve production efficiency and serve domestic economic growth[1]. In recent years, China's OFDI has been rapid development, making it the world's second-largest foreign investor. China's "going out" strategy and management system are constantly

*Corresponding author adjusted, and OFDI is at it's best period in history. Especially since "The Belt and Road" initiative was launched in 2013, China has increased its investment in countries along the Belt and Road route and promoted international capacity cooperation. It can be seen that the countries along The Belt and Road are gradually becoming one of the important places for China's foreign direct investment.

However, compared with mature enterprises in Europe and the United States, China's multinational investment companies are relatively weak in competitiveness and lack experience in foreign direct investment, so they will face many risks and challenges in the process of "going out". As far as China's investment in countries along "The Belt and Road" is concerned, the projects that have been put on hold and even cancelled have emerged one after another, which caused serious economic losses to the Chinese government and related enterprises, and also brought a shadow to the smooth progress of China's OFDI.

Therefore, exploring the influencing factors of China's OFDI development from the big environment is conducive to China's formulation of a reasonable foreign direct investment strategy, smoothly promoting the "going out" project, and it also has certain research value and practical reference significance for cooperation and investment in countries along "The Belt and Road". From a more macro perspective, it can also provide theoretical support and suggestions for OFDI in maintaining the stability, continuity and coordinated development of the national economy. To this end, this study takes the analysis of the influencing factors of outward foreign direct investment as the starting point, selects the relevant index data of China's OFDI from 2000 to 2015, and uses the principal component analysis method to explore the influencing factors of China's OFDI development, expect to get the corresponding results and give relevant policies and recommendations.

This paper will explore the problems of research according to the following structure. The first part mainly expounds the background of the topic; The second part will describe the literature results of relevant research at home and abroad; The empirical analysis of the relevant years in China is in the third part, we select relevant indicator data and use SPSS24.0 software to obtain the results and conclusions; and finally through the results of the large environmental empirical 
conclusion, to provide relevant suggestions and policy opinions for China's outward direct foreign investment in other countries , especially the along "The Belt and Road" countries.

\section{LITERATURE REVIEW}

With the deepening of economic globalization and the acceleration of international capital flows, international direct investment has become an important link between world economic activities and links. Scholars at home and abroad have also had multi-perspective research and investigation on the development of OFDI and its influencing factors, and the research methods and tools have become more and more diversified, and have obtained fruitful research results.

There have been many empirical studies on OFDI along time ago. Blomstrom, Konan and Lipsey, for example, study the characteristics of Japan's OFDI and conclude that the optimization of Japan's economic structure, especially industrial structure, is closely related to its OFDI, Musgrave found that U.S. OFDI can significantly lead to the long-term sustained growth of domestic income level, and the role of the main way of promoting the productivity level of home enterprises and promote the adjustment and upgrading of domestic industrial structure[2]. Some scholars have also conducted research on the factors affecting OFDI.W. Christaller(1972) and A. Lorch (1972) thought that the economic factors, political factors, and human capital factors of the host country will have an important impact on international investment behavior. Market and profit will play a decisive role in the selection. .Dunning (1991) pointed out that in the international production process, the level of foreign direct investment development of a country is positively affected by the level of economic development and the scale of foreign investment. In addition, he further found that there is a dual relationship between OFDI and exports[3]. Tsai (1994) found that the size of the host country's market has a greater impact on the foreign direct investment of the investing country when studying foreign direct investment in developing countries.

At the same time as foreign scholars carry out related research, relevant scholars in China have also discussed and systematically studied the factors affecting the development of OFDI. Huifang Chen and Xiang Ruan(2004) used the gravity model to analyze China's foreign direct investment behavior in 32 host countries and regions, and found that the host country's total economic scale, per capita income level and bilateral trade scale were positively correlated with OFDI, while the home country and the geographical distance between host countries has a negative impact on OFDI behavior[5]. Daying Yan et al (2009) used the multiple regression model to empirically analyze the OFDI of Chinese enterprises, and believed that corporate financing capacity, overseas relationship resource distribution and government foreign investment policies and systems are important factors affecting the motivation and development of foreign direct investment of enterprises[6]. Yanyan Ouyang(2010)constructed the least squares regression model to explore the factors of china's OFDI reverse technology spillover, and the conclusion of the study shows that China's total economic volume, the host country's research and development capital stock, per capita income level and the real exchange rate level are important factors affecting the reverse technology spillover of China's OFDI[7]. Yaqing Yu (2010) and Wen Chen (2012)pointed out that China's OFDI is mainly affected by factors such as economic growth, average wage level, legal environment, political risk and geographical distance and cultural differences between the two countries. By establishing a linear model of the logarithm of OFDI[8][9]. En Chen and Fangfang Wang (2011) found that the market size of the host country was the main factor of China's OFDI[4].

In summary, scholars at home and abroad have made relevant studies on the impact factors of the development of OFDI, and obtained the conclusions and results of research with different views. However, most domestic and foreign scholars from the theory of OFDI research, or bias based on using measurement analysis tools to study the high level of economic development of OFDI in countries, the results vary widely, Conclusion is not uniform, and the scope and indicators are relatively limited. On the basis of previous research, this paper explores the influence factors of the development of China's OFDI in combination with the statistical factor analysis model system, hoping to improve the research results and give relevant suggestions to China.

\section{INDEX VARIABLE CONSTRUCTION AND DATA SELECTION}

Principal Component Analysis (PCA) is a commonly used multivariate statistical method in the field of statistics. Karl Pearson first proposed to use the idea of dimension reduction to translate multiple indicators into a few comprehensive indicators. This method has been more widely used in the evaluation of sociology, economics, and management in recent years. It uses the idea of variable dimension reduction to"reconstruct" multiple complex and existing variables or combinations of indicators into information that does not overlap each other, but can reflect most of the information of the original variables, simplifying the problem and getting more Scientific and effective results.

\section{A. Indicator variable construction}

The development of OFDI has been affected by many factors at home and abroad. We have also obtained quite rich results from previous studies. Combining the previous literature, considering the comprehensiveness of the selection of indicators, in this paper, we will examine the economic factors which affecting the development of OFDI from the following evaluation systems.

1) Domestic economic indicators will affect the development of China's foreign direct investment

Domestic economic indicators will affect China's OFDI, and China's domestic macroeconomic operation will affect China's macroeconomic regulation and control, which will inevitably lead to OFDI a certain influence. Therefore, domestic economic indicators are one of the indispensable factors for studying China's OFDI.. In this study we select $\mathrm{X} 1, \mathrm{X} 2, \mathrm{X} 3 . \mathrm{X} 4$ which in TABLE I as a measure of domestic economic development, on behalf of China to carry out external the domestic economic environment and situation of direct investment. 
2) Foreign economic indicators will affect the development of China's foreign direct investment

China's foreign economic indicators are mainly reflected in China's foreign trade and economic development. With the continuous improvement of China's opening up to the outside world, the exchanges between China and other countries have gradually increased, and the dependence on foreign trade has increased. This has provided favorable benefits for Chinese enterprises to carry out OFDI.

The foreign economic indicators constructed in this paper include $\mathrm{X} 5, \mathrm{X} 6, \mathrm{X} 7, \mathrm{X} 8$ which in TABLE I , indicating China's

TABLE I is an indicator description:

TABLE I. SELECTED INDICATORS AND DESCRIPTIONS

\begin{tabular}{|c|c|c|}
\hline $\begin{array}{c}\text { varia } \\
\text { ble }\end{array}$ & Variable name & Variable description \\
\hline $\mathbf{Y}$ & $\begin{array}{c}\text { Net outward } \\
\text { foreign direct } \\
\text { investment }\end{array}$ & $\begin{array}{l}\text { Measuring the scale and development } \\
\text { level of foreign direct investment of } \\
\text { Chinese enterprises }\end{array}$ \\
\hline $\mathbf{X}_{1}$ & GDP & $\begin{array}{l}\text { Measuring China's economic situation } \\
\text { and economic strength and market size }\end{array}$ \\
\hline $\mathbf{X}_{2}$ & CPI & Measuring China's inflation or contraction \\
\hline $\mathbf{X}_{3}$ & $\begin{array}{l}\text { Number of Top } \\
500 \text { Chinese }\end{array}$ & $\begin{array}{l}\text { Measuring the level of internationalization } \\
\text { and competitiveness of Chinese }\end{array}$ \\
\hline $\mathbf{X}_{4}$ & Fiscal expenditure & $\begin{array}{l}\text { Reflecting the size of the country's } \\
\text { financial resources }\end{array}$ \\
\hline $\mathbf{X}_{5}$ & exchange rate & $\begin{array}{l}\begin{array}{l}\text { Measuring China's import and export } \\
\text { situation }\end{array} \\
\end{array}$ \\
\hline $\mathbf{X}_{6}$ & Trade dependence & $\begin{array}{l}\text { Measuring the level and extent of China's } \\
\text { opening up }\end{array}$ \\
\hline $\mathbf{X}_{7}$ & $\begin{array}{l}\text { Amount of } \\
\text { foreign direct } \\
\text { invectment in }\end{array}$ & $\begin{array}{l}\text { Measuring the scale and ability of China } \\
\text { to attract overseas enterprises }\end{array}$ \\
\hline $\mathbf{X}_{8}$ & $\begin{array}{l}\text { Foreign exchange } \\
\text { reserves }\end{array}$ & $\begin{array}{l}\text { Measuring China's foreign currency } \\
\text { wealth is the basis for enterprises to carry } \\
\text { out foreign investment }\end{array}$ \\
\hline $\mathbf{X}_{9}$ & $\begin{array}{l}\text { Global economic } \\
\text { growth rate }\end{array}$ & $\begin{array}{l}\text { Measuring the world economic situation } \\
\text { and the external investment environment }\end{array}$ \\
\hline $\mathbf{X}_{10}$ & $\begin{array}{l}\text { World Outward } \\
\text { Investment } \\
\text { Growth Rate }\end{array}$ & $\begin{array}{l}\text { Measuring the state of global capital flows } \\
\text { and the development of foreign investment }\end{array}$ \\
\hline
\end{tabular}

degree of openness and the economic basis of foreign direct investment and China's trade competitiveness.

\section{3) World economic indicators will affect China's} foreign direct investment development

The trend of the world economy and the global economic environment will have an impact on China's overseas investment choices, which in turn will affect China's OFDI. Therefore, we also consider this indicator. In terms of world economic indicators, it includes two variables, $\mathrm{X} 9, \mathrm{X} 10$, which are used to measure the external conditions and environment of foreign direct investment of domestic enterprises.

TABLE II. CORRELATION COEFFICIENT ANALYSIS RESULT

\begin{tabular}{|c|c|c|c|c|c|c|c|c|c|c|}
\hline & $\begin{array}{l}X \\
1 \\
\end{array}$ & $\begin{array}{l}X \\
2 \\
\end{array}$ & $X_{3}$ & $\begin{array}{l}X \\
4 \\
\end{array}$ & $\begin{array}{l}X \\
5 \\
\end{array}$ & $\begin{array}{l}X \\
6 \\
\end{array}$ & $\begin{array}{l}X \\
7\end{array}$ & $\begin{array}{l}X \\
8 \\
\end{array}$ & $\begin{array}{l}\mathrm{X} \\
9\end{array}$ & $\begin{array}{l}X \\
10 \\
\end{array}$ \\
\hline $\mathrm{X}_{1}$ & 1 & $\begin{array}{c}0 . \\
26 \\
2\end{array}$ & $\begin{array}{l}.99 \\
4 * \\
*\end{array}$ & $\begin{array}{l}.9 \\
96 \\
* *\end{array}$ & $\begin{array}{c}- \\
96 \\
6^{*} \\
*\end{array}$ & $\begin{array}{c}- \\
0.3 \\
59\end{array}$ & $\begin{array}{l}9 \\
4 \\
6 \\
* \\
*\end{array}$ & $\begin{array}{l}.96 \\
1 * \\
*\end{array}$ & $\begin{array}{c}- \\
0.0 \\
58\end{array}$ & $\begin{array}{c}- \\
0.0 \\
97\end{array}$ \\
\hline $\mathrm{X}_{2}$ & $\begin{array}{l}0.2 \\
62\end{array}$ & 1 & $\begin{array}{c}0.2 \\
05\end{array}$ & $\begin{array}{c}0 . \\
20 \\
4\end{array}$ & $\begin{array}{c}- \\
0.3 \\
14\end{array}$ & $\begin{array}{l}0.4 \\
85\end{array}$ & $\begin{array}{l}0 \\
\dot{4} \\
4 \\
9\end{array}$ & $\begin{array}{l}0.3 \\
61\end{array}$ & $\begin{array}{l}0.3 \\
87\end{array}$ & $\begin{array}{l}0.4 \\
06\end{array}$ \\
\hline $\mathrm{X}_{3}$ & $\begin{array}{c}.99 \\
4 * \\
*\end{array}$ & $\begin{array}{c}0 . \\
20 \\
5\end{array}$ & 1 & $\begin{array}{l}.9 \\
96 \\
* *\end{array}$ & $\begin{array}{c}- \\
.94 \\
6^{*} \\
*\end{array}$ & $\begin{array}{c}- \\
0.4 \\
19\end{array}$ & $\begin{array}{l}9 \\
1 \\
3 \\
* \\
*\end{array}$ & $\begin{array}{l}.93 \\
7 * \\
*\end{array}$ & $\begin{array}{c}- \\
0.0 \\
71\end{array}$ & $\begin{array}{c}- \\
0.0 \\
85\end{array}$ \\
\hline $\mathrm{X}_{4}$ & $\begin{array}{c}.99 \\
6^{*} \\
*\end{array}$ & $\begin{array}{c}0 . \\
20 \\
4\end{array}$ & $\begin{array}{l}.99 \\
6 * \\
*\end{array}$ & 1 & $\begin{array}{c}- \\
.95 \\
0 * \\
*\end{array}$ & $\begin{array}{c}- \\
0.4 \\
14\end{array}$ & $\begin{array}{l}9 \\
2 \\
5 \\
* \\
*\end{array}$ & $\begin{array}{l}.93 \\
7 * \\
*\end{array}$ & $\begin{array}{c}- \\
0.0 \\
8\end{array}$ & $\begin{array}{c}- \\
0.1 \\
09\end{array}$ \\
\hline $\mathrm{X}_{5}$ & $\begin{array}{c}- \\
96 \\
6 * \\
*\end{array}$ & $\begin{array}{c}- \\
0 . \\
31 \\
4\end{array}$ & $\begin{array}{l}- \\
.94 \\
6 * \\
*\end{array}$ & $\begin{array}{c}- \\
.9 \\
50 \\
* *\end{array}$ & 1 & $\begin{array}{c}0.3 \\
6\end{array}$ & $\begin{array}{l}9 \\
5 \\
2 \\
* \\
*\end{array}$ & $\begin{array}{l}- \\
.98 \\
1 * \\
*\end{array}$ & $\begin{array}{c}0.1 \\
6\end{array}$ & $\begin{array}{c}0.2 \\
17\end{array}$ \\
\hline $\mathrm{X}_{6}$ & $\begin{array}{c}- \\
0.3 \\
59\end{array}$ & $\begin{array}{c}0 . \\
48 \\
5\end{array}$ & $\begin{array}{c}- \\
0.4 \\
19\end{array}$ & $\begin{array}{c}- \\
0 . \\
41 \\
4\end{array}$ & $\begin{array}{c}0.3 \\
6\end{array}$ & 1 & $\begin{array}{l}- \\
0 \\
1 \\
6 \\
3\end{array}$ & $\begin{array}{c}- \\
0.2 \\
26\end{array}$ & $\begin{array}{l}.59 \\
6^{*}\end{array}$ & $\begin{array}{c}0.4 \\
12\end{array}$ \\
\hline $\mathrm{X}_{7}$ & $\begin{array}{c}.94 \\
6^{*} \\
*\end{array}$ & $\begin{array}{c}0 . \\
44 \\
9\end{array}$ & $\begin{array}{c}.91 \\
3 * \\
*\end{array}$ & $\begin{array}{l}.9 \\
25 \\
* *\end{array}$ & $\begin{array}{c}- \\
95 \\
2 * \\
*\end{array}$ & $\begin{array}{c}- \\
0.1 \\
63\end{array}$ & 1 & $\begin{array}{c}97 \\
0 * \\
*\end{array}$ & $\begin{array}{l}0.0 \\
21\end{array}$ & $\begin{array}{c}- \\
0.0 \\
87\end{array}$ \\
\hline $\mathrm{X}_{8}$ & $\begin{array}{c}.96 \\
1 * \\
*\end{array}$ & $\begin{array}{c}0 . \\
36 \\
1\end{array}$ & $\begin{array}{c}.93 \\
7 * \\
*\end{array}$ & $\begin{array}{l}.9 \\
37 \\
* *\end{array}$ & $\begin{array}{c}- \\
.98 \\
1 * \\
*\end{array}$ & $\begin{array}{c}- \\
0.2 \\
26\end{array}$ & $\begin{array}{l}9 \\
7 \\
0 \\
* \\
*\end{array}$ & 1 & $\begin{array}{c}- \\
0.0 \\
36\end{array}$ & $\begin{array}{c}- \\
0.1 \\
26\end{array}$ \\
\hline $\mathrm{X}_{9}$ & $\begin{array}{c}- \\
0.0 \\
58\end{array}$ & $\begin{array}{c}0 . \\
38 \\
7\end{array}$ & $\begin{array}{c}- \\
0.0 \\
71\end{array}$ & $\begin{array}{c}- \\
0 . \\
08\end{array}$ & $\begin{array}{c}0.1 \\
6\end{array}$ & $\begin{array}{l}.59 \\
6^{*}\end{array}$ & $\begin{array}{l}0 \\
0 \\
0 \\
2 \\
1\end{array}$ & $\begin{array}{c}- \\
0.0 \\
36\end{array}$ & 1 & $\begin{array}{c}.71 \\
7 * \\
*\end{array}$ \\
\hline $\begin{array}{l}\mathrm{X}_{1} \\
0\end{array}$ & $\begin{array}{c}- \\
0.0 \\
97\end{array}$ & $\begin{array}{c}0 . \\
40 \\
6\end{array}$ & $\begin{array}{c}- \\
0.0 \\
85\end{array}$ & $\begin{array}{c}0 . \\
10 \\
9\end{array}$ & $\begin{array}{l}0.2 \\
17\end{array}$ & $\begin{array}{l}0.4 \\
12\end{array}$ & $\begin{array}{l}- \\
0 \\
0 \\
0 \\
8 \\
7\end{array}$ & $\begin{array}{c}- \\
0.1 \\
26\end{array}$ & $\begin{array}{c}71 \\
7 * \\
*\end{array}$ & 1 \\
\hline
\end{tabular}




\section{B. Data selection}

According to the data availability of selected indicators, and to ensure that there are sufficient years to reflect the situation of OFDI since China implemented the "going out" strategy and the "The Belt and Road" strategy in recent years, moreover can use the principal component analysis model to obtain relevant conclusions, this study will select the data of the above 10 variables from 2000 to 2015 to conduct research.At the same time, we have unified the data for each year (100 million yuan) according to relevant standards

\section{DATA ANALYSIS}

The data analysis software used in this study is SPSS24.0.

\section{A. S tandardized processing of data}

The units of measurement between the indicators of this study are different. Therefore, there are dimensional problems in the study of data objects, and the dimensional problems will have a biased effect on the statistical analysis results, resulting in the accuracy of the prediction results. In order to make the research more scientific and rigorous, eliminate the dimensional problems and statistical errors between variables, and make the data more comparable, this study firstly standardized the original data with SPSS24.0. The standardized data processing form is more consistent and more coordinated, which can lay a good foundation for the subsequent better principal component analysis.

TABLE III. KMO STATISTIC AND BARTLETT SPHERICAL TEST

\begin{tabular}{|c|c|c|}
\hline KMO and Bartlett test & \multicolumn{2}{|c|}{0.681} \\
\hline KMO sampling suitability & \multicolumn{2}{|c|}{} \\
\hline Bartlett sphericity test & Approximate chi square & 295.354 \\
\hline & Degree of freedom & 45 \\
\hline & Significant & 0 \\
\hline
\end{tabular}

TABLE IV. TOTAL VARIANCE INTERPRETATION

\begin{tabular}{|c|c|c|c|c|c|c|}
\hline $\begin{array}{c}\text { ing } \\
\text { red } \\
\text { ien } \\
\boldsymbol{t}\end{array}$ & \multicolumn{3}{|c|}{ Initial eigenvalue } & \multicolumn{3}{c|}{$\begin{array}{c}\text { Extracting the sum of } \\
\text { squared loads }\end{array}$} \\
\cline { 2 - 7 } & total & $\begin{array}{c}\text { Percent } \\
\text { age of } \\
\text { ariance }\end{array}$ & $\begin{array}{c}\text { Cumula } \\
\text { ive \% }\end{array}$ & total & $\begin{array}{c}\text { Percent } \\
\text { age of } \\
\text { varianc } \\
\boldsymbol{e}\end{array}$ & $\begin{array}{c}\text { Cum } \\
\text { ulati } \\
\text { ve\% }\end{array}$ \\
\hline 1 & 6.032 & 60.318 & 60.318 & $\begin{array}{c}6.03 \\
2\end{array}$ & 60.318 & $\begin{array}{c}60.3 \\
18\end{array}$ \\
\hline 2 & 2.521 & 25.212 & 85.531 & $\begin{array}{c}2.52 \\
1\end{array}$ & 25.212 & $\begin{array}{c}85.5 \\
31\end{array}$ \\
\hline 3 & 0.774 & 7.738 & 93.268 & $\begin{array}{c}0.77 \\
4\end{array}$ & 7.738 & $\begin{array}{c}93.2 \\
68\end{array}$ \\
\hline 4 & 0.414 & 4.138 & 97.406 & & & \\
\hline 5 & 0.168 & 1.678 & 99.084 & & & \\
\hline 6 & 0.055 & 0.549 & 99.633 & & & \\
\hline 7 & 0.03 & 0.3 & 99.933 & & & \\
\hline 8 & 0.005 & 0.054 & 99.986 & & & \\
\hline 9 & 0.001 & 0.012 & 99.998 & & & \\
\hline 10 & 0 & 0.002 & 100 & & & \\
\hline
\end{tabular}

TABLE V. FACTOR LOAD MATRIX ANALYSIS

\begin{tabular}{|c|c|c|c|c|c|c|}
\hline variable & \multicolumn{3}{|c|}{ Initial factor load matrix } & \multicolumn{3}{c|}{ Post-rotation factor load matrix } \\
\hline & $F_{I}$ & $F_{2}$ & $F_{3}$ & $F_{I}$ & $F_{2}$ & $F_{3}$ \\
\hline$X_{I}$ & 0.992 & 0.039 & 0.088 & 0.995 & -0.013 & -0.053 \\
\hline$X_{2}$ & 0.289 & 0.75 & -0.441 & 0.326 & 0.246 & 0.82 \\
\hline$X_{3}$ & 0.98 & 0 & 0.164 & 0.984 & 0.009 & -0.136 \\
\hline$X_{4}$ & 0.984 & -0.008 & 0.141 & 0.986 & -0.014 & -0.123 \\
\hline$X_{5}$ & -0.988 & 0.017 & 0.089 & -0.977 & 0.171 & -0.045 \\
\hline$X_{6}$ & -0.379 & 0.748 & -0.396 & -0.337 & 0.342 & 0.793 \\
\hline$X_{7}$ & 0.961 & 0.187 & -0.126 & 0.964 & -0.038 & 0.206 \\
\hline$X_{8}$ & 0.976 & 0.109 & -0.084 & 0.975 & -0.071 & 0.123 \\
\hline$X_{9}$ & -0.121 & 0.856 & 0.32 & -0.031 & 0.864 & 0.32 \\
\hline$X_{10}$ & -0.166 & 0.787 & 0.485 & -0.071 & 0.924 & 0.15 \\
\hline
\end{tabular}

\section{B. Correlation coefficient analysis and multi-collinearity} test

In order to conduct PCA in this study, it is necessary to conduct routine tests on the necessity and feasibility of principal component analysis, which will make the research more rigorous. Therefore, we need to test the degree of correlation between the various variables, and to test that these variables are not suitable for the next principal component analysis. The methods we use here include two kinds of correlation analysis methods, the KMO statistic and the Bartlett spherical test. The test results are shown in TABLE II and III, respectively.

From the test, we get the correlation degree between the partial variables up to 0.996 in the correlation coefficient table, so we can determine the correlation between the 10 index variables and have the premise of principal component analysis. In addition, the KMO measure compares the correlation coefficient between the observed original variables and the magnitude of the partial correlation coefficient. A large KMO measure allows us to perform principal component analysis. The KMO statistic value of this study is 0.681, which is more suitable for principal component analysis. Bartlett sphericity test is used to test whether the correlation matrix is a unit matrix, that is whether the variables are independent. If the statistical value of the Bartlett spherical test is large and the corresponding associated probability value is less than the level of significance given by the user, the null hypothesis should be rejected.The Bartlett spherical test result of this study is 295.354, and there is a significance level of less than 0.05, indicating that the principal component analysis model is well constructed, and the next statistical analysis can be carried out accordingly.

\section{Principal component analysis}

Based on the applicability test of principal component analysis model, this paper uses SPSS24.0 software to analyze the variance contribution analysis and principal component analysis common factors of the selected 10 index variables. The analysis results are shown in TABLEIV, and Fig.1 is a gravel diagram after principal component analysis.According to the PCA common factor extraction rule, the eigenvalues of variable 1 and variable 2 are all greater than 1 , but in order to make the extracted main components better explain all the selected indicators, we extract three principal components in this study. The overall interpretation level reached $93.28 \%$, which basically reflected most of the information covered by the original data, therefore, this study selected three common factors to interpret the main factors affecting the development of China's OFDI. And we can also see from the gravel diagram that after the third eigenvalue point, the connection of the eigenvalue points tends to be gentle, so it is reasonable to choose three common factors. 


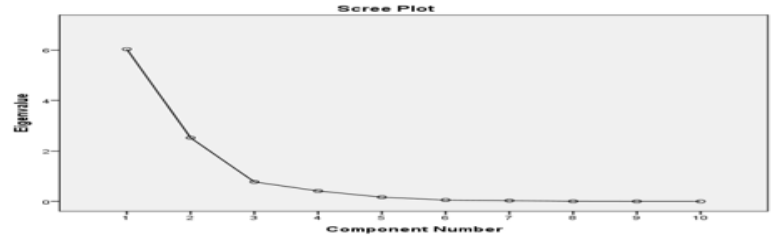

\section{Factor load matrix analysis}

After the PCA is completed to obtain three common factors, the variance maximization method is used to obtain the result of the rotated factor load matrix. The orthogonal rotation method with the largest variance makes each column element in the rotated factor load array as far as possible, that is, polarization to 0 or 1 , so that each main factor only has a high load corresponding to a few variables. The rest of the load is small, and each variable has a high load on only a few principal factors, which is more conducive to our more logical factors. Table 5 shows the results of the factor loading matrix after initial and rotation. Generally, the higher the factor load, the larger the amount of information contained in the factor, and the stronger the interpretation of the factors affecting the development of China's foreign direct investment.

According to the results in TABLEV, the initial factor load matrix and the rotated factor load matrix analysis results still have some degree of change and gap. According to the data of the post-rotation load matrix, we can get: from the first factor F1, domestic GDP, the number of Chinese companies in the top 500, fiscal expenditure, exchange rate, amount of foreign direct investment in China and foreign exchange reserves have a large load value of 0.96 or above. These factors not only reflect the overall financial situation of China, but also reflects the economic factors of economic ties with foreign countries. Combining two, we can name F1 as "domestic and domestic macroeconomic factors". In terms of the second factor F2, the factor load values of the global economic growth rate and the world OFDI growth rate are 0.864 and 0.924 respectively. The above two variables reflecting the macro external economy. The impact of the environment on China's foreign direct investment is considered as a "global investment environment factor".n terms of the third factor F3, the factor load values of CPI and trade dependence are 0.82 and 0.793 , respectively. These two factors mainly reflect the degree of inflation or contraction in China, and the degree of openness. All of them can indirectly reflect the policy of foreign direct investment in the home country, so we define it as a "domestic policy factor". So far, this study has reduced the 10 factors that may affect the foreign direct investment of Chinese enterprises to the three main components of "domestic and domestic macroeconomic factors", "global investment environmental factors" and "domestic policy factors" through PCA, to examine the economic factors that affect the development of China's OFDI.

From the results, we can infer the following conclusions. First, in the "domestic and domestic macroeconomic factors" (F1), the GDP, the number of top 500 Chinese enterprises, the fiscal expenditure, the exchange rate, amount of foreign direct investment in China and foreign exchange reserves have all had a significant positive impact on China's OFDI development and are the important factors in promoting China's OFDI; Secondly, in terms of "global investment environment factor" (F2), the global economic growth rate and the world OFDI growth rate have also significantly affected the overseas investment behavior of Chinese enterprises, both of which are as high as 0.8 or more, indicating that the external investment environment and the trend of international trade will strongly promote Foreign direct investment behavior of Chinese enterprises; Finally, in terms of "domestic policy factors" (F3), CPI and trade dependence also have a positive impact on China's OFDI, indicating that China's healthy and rational fiscal policy and opening up policy have promoted China's OFDI.

According to the empirical results of the research, we can conclude that if a country's enterprises want to invest smoothly overseas, we must consider three factors, the most basic of which is of course the domestic and domestic macroeconomic factors, because all the investment must be based on the national economy, based on the domestic and international economic development and the company's own operating strength as the fundamental conditions; Secondly, a stable global investment environment can provide external guarantees for the country's foreign direct investment, so that the scale and quality of overseas investment of enterprises can be continuously improved, thus promoting the steady advancement of various domestic economic undertakings; Finally, the national health and sound policies have an indelible effect on a country's foreign direct investment. OFDI requires the help and support of national policies.

\section{CONCLUSIONS AND POLICY RECOMMENDATIONS}

By using SPSS24.0 software to analyze the data analysis of 10 indicators from 2000 to 2015, we can conclude that China's OFDI is mainly affected by three factors.(1) The domestic and domestic macroeconomic factors, in this study, which includes GDP, the number of top 500 Chinese enterprises, fiscal expenditure, exchange rate, amount of foreign direct investment in China and foreign exchange reserves, the reason why they all have a significant positive impact on the development of China's OFDI lies in the fact that these domestic and foreign economic factors are witnesses to China's economic strength. The improvement of economic strength has promoted the enhancement of core competitiveness in various aspects of national management and technology, creating superior internal conditions for China's OFDI; And the stronger host country currency is more favorable to the investment of multinational companies, and provides greater demand for the local market; Finally, the increase of foreign exchange reserves can not only enhance China's ability of macro-control, but also help maintain the international reputation of the country and enterprises. Therefore, it will help expand international trade, attract foreign investment in China, and increase China's OFDI. Therefore, this factor is an important factor in promoting China's OFDI;(2) The global investment environment factor, the investment environment is an objective factor affecting OFDI. A good global investment 
environment will promote the ability of countries to attract foreign investment, and at the same time reduce the risk of host country investment. Therefore, it is beneficial for the host country to make correct choices, increase the ratio of OFDI, and promote economically common progress in the countries concerned. From the above conclusions, the development of China's OFDI is not the result of a single factor, but is influenced by the comprehensive domestic and international economic and trade factors and the environment as well as domestic policies. To this end, to effectively promote the development of Chinese enterprises, not only need to maintain a stable domestic economic trend, make full use of the trend of the global economic and trade environment to continuously create more favorable opportunities for China's OFDI,but also requires the state to make healthy and reasonable and long-term policies to give institutional and policy support.

With China's "going out" in 2000 and "The Belt and Road" strategy in 2003, China has accelerated its pace of going global, and OFDI has also made a qualitative leap, but it also faces many challenges.In order to better stand on the heels in the process of "going out",and have better foreign direct investment performance in the countries along "The Belt and Road". We can give certain policy recommendations from our analysis of the factors of global foreign direct investment:

First and foremost, if the country wants to expand OFDI, it must first lay a good foundation for the country's economy, and steadily and vigorously improve its economic development level, so as to create a good economic environment and guarantee macroeconomic stability and ensure the stability and continuous operation of the macro economy and avoid the risk of economic fluctuations so as not to adversely affect the expectations and confidence of overseas investment companies.

Secondly, we need to grasp the global economic investment environment from the overall perspective. When making direct foreign investment, we must comprehensively consider the global and world economic growth and the growth rate of foreign investment, and then choose to develop a relatively mature host country for cooperation and exchange, and gradually optimize the industrial and regional structure of Chinese enterprises in the "Belt and Road" overseas investment, and enhance the efficiency of overseas investment.

Finally, the government should strengthen exchanges and familiarity with other countries along "The Belt and Road", including other countries that intend to trade and invest with our country. Only by knowing ourselves and knowing each other can we formulate a long-term foreign direct investment blueprint.Of course, it is also necessary to encourage domestic enterprises with investment strength and qualifications to speed up the pace of "going out", in improving the scale of investment in countries along the Belt and Road, China's enterprises to promote the promotion and return of investment efficiency, and to continuously improve the level and quality of opening up to the outside world, in order to better meet the national "going out" strategy.

\section{LIMITATION}

The research in this paper is of great significance for China to better promote the national direct foreign investment along "The Belt and Road". It is possible to draw the factors that influence the country's OFDI from the empirical conclusions, so as to make relevant policies and strategy from these factors and put forward relevant opinions. But this article also has certain limitations.For example, most of the indicators we selected are related to the economic level. The other aspects of technology or host countries are not involved. Therefore, we cannot give relevant conclusions and opinions and policies to other levels of influence.Secondly, the data we selected is the 2000-2015 limit. It has not been updated to the most recent year, nor has it extended to the period before the implementation of the "going out" strategy. Therefore, it is impossible to make China's direct external relevant comparison of investment.

\section{ACKNOWLEDGMENT}

I want to express my heartfelt gratitude and most sincere respect to all those who have helped me during this period. I would like to thank my teacher, Mrs. Yang, whether in scientific research or life will give me encouragement and help, let me always walk on the road beyond self, her scientific research spirit is also my always pointing lights.

\section{REFERENCES}

[1] Yuanyuan Gu, Bin Qiu. Studying in China and Foreign Direct Investment in China-An Empirical Study Based on National Data along the Belt and Road Initiative[J].International Trade Issues,2017(04):83-94.

[2] MUSGR AVE P. Direct investment abroad and the multinationals: effects on the United States economy $[\mathrm{M}]$. Washington. D. C. Government Printing Office, 1975: 33-42.

[3] Dunning J,, "Multinational Enterprise and Global Economy" , Journal of International Business Studies, Vol. 72, No.6, 1991, pp. 120 145 .

[4] En Chen, Fangfang Wang.An Empirical Analysis of the Factors Affecting China's Foreign Direct Investment-Based on the Investigation of International Panel Data from 2007 to $2009[\mathrm{~J}]$.Commercial Economics and Management,2011(08):43-50.

[5] Huifang Cheng, Xiang Yu .Analysis of Location Selection of China's Foreign Direct Investment by Gravitational Model[J].World Economy,2004(11):23-30.

[6] Daying Yan, Junjie Hong, Ren Bing. Determinants of Chinese Enterprises' Foreign Direct Investment: Empirical Analysis Based on System Perspective[J]. Nankai Management Review, 2009, 12(06): 135$142+149$.

[7] Yanyan Ouyang .Analysis of the Factors Affecting the Reverse Technology Spillover of China's Foreign Direct Investment[J].World Economy Study,2010(04):66-71+89

[8] Yaqing Yu.An Empirical Analysis of the Factors Affecting China's Foreign Direct Investment Behavior[J].World Economic Situation, 2010(03):11-15.

[9] Wen Chen .An Empirical Study of Determinants of China's Foreign Direct Investment_-An Empirical Analysis Based on Dynamic Panel Data Model[J].Science and Technology Information,2012(11):161-162.

[10] Jing Bian, Wei Zhang. The Trade Effect of China's Foreign Direct Investment_-Based on the Research of the "Belt and Road Initiative"[J] Journal of Beijing Technology and Business University (Social Science Edition), 2019(05): 34-44.

[11] Jialin Li,Yuanzhao Zhang .The Risks and Control Measures of Chinese Enterprises' Foreign Investment under the New Situation[J].AsiaPacific Economy,2019(04):88-94. 